УДК 621.923.7

I. V. Kuzio, V. M. Zakharov, V. M. Korendiy

Lviv Polytechnic National University

\title{
MODELLING THE PROCESS OF DRESSING THE LAPS OF VIBRATORY FINISHING MACHINE
}

(C) Kuzio I. V., Zakharov V. M., Korendiy V. M., 2018

doi

The purpose of the paper. Substantiation of structure (design), parameters and operation modes of the improved vibratory finishing machine. Analysis of dynamical processes which occur during "lap over lap" dressing. Investigation methodology. Mathematical model of motion of the mechanical system of vibratory finishing machine was developed on the basis of Lagrange differential equations of the second order. For the purpose of describing friction between the working surfaces of the laps, the Coulomb friction model was used. Stiffness parameters of all elastic elements were modeled in accordance with the Hooke's law. Energy losses in elastic elements during their tension-compression were taken into account by corresponding coefficients of dissipation (damping). Simulation modelling of motion of the machine's mechanical oscillatory system was carried out in MathCAD software by means of solving the derived differential equations of the system's motion using the numerical methods of Runge-Kutta. Obtained results. Structural and functional peculiarities of the improved vibratory finishing machine for lapping flat surfaces of cylindric and prismatic parts were considered. Design (calculation) diagram of its mechanical oscillatory system was substantiated and differential equations of motion of oscillating masses were derived. Simulation modelling of the laps' motion during their dressing was carried out and the correspondence of the obtained results to the input modelling parameters (operation in near-resonance mode with the given oscillation amplitudes) was analyzed. Scientific novelty. For the first time we obtained following results: spatial design (calculation) diagram of mechanical oscillatory system of the improved vibratory finishing machine was proposed; mathematical model of plane-parallel motion of oscillating masses (with circular trajectories of oscillations) was developed; possibilities of performing the laps dressing using "lap over lap" method were substantiated by means of ensuring their circular oscillations. Practical value. The results of the performed investigations can be used during designing new and improving existing structures of vibratory finishing machines for finishing treatment (lapping) of flat surfaces of cylindric and prismatic parts.

Keywords: lap, vibratory finishing machine, inertial parameters, stiffness parameters, resonance, energy dissipation, oscillatory system, plane-parallel motion, circular oscillations.

Introduction and problem stating. Vibratory finishing machines are usually used for performing finishing technological operations, in particular, for lapping flat surfaces of cylindric and prismatic parts [1]. One of the possible designs of such machines is presented in Fig. 1. The basic component elements of the machine are the upper 1 and the lover 2 laps, drive 3 (in this case - electromagnetic one), and the system of elastic elements 4-6 which connect movable parts with each other of the machine and are used for mounting (installing) the machine on the fixed frame (base, foundation etc.). In particular, the springs 4 are placed between reactive (exciting) masses 7 (electromagnets' armatures) and electromagnets' frames 8 attached to the lower lap 2. The rod-type elastic element 5 connects the upper 1 and the lower 2 laps. In order to mount (install) the machine on the fixed frame (base, foundation etc.), the coil cylindrical springs 6 are used.

The oscillations of the machine's working bodies (laps) are excited by electromagnets 3 through the elastic systems 4 and 5. Taking into account the fact that each of three couples of electromagnets are placed (attached) with the angle shift of $60^{\circ}$ on the circle of the lower lap, by means of rational setting the control system of electromagnetic excitation up and of rational choosing the inertial and stiffness parameters of the mechanical oscillatory system of the machine, it is possible to ensure antiphase oscillations of the laps along the circular trajectories and to perform "lap over lap" dressing. 


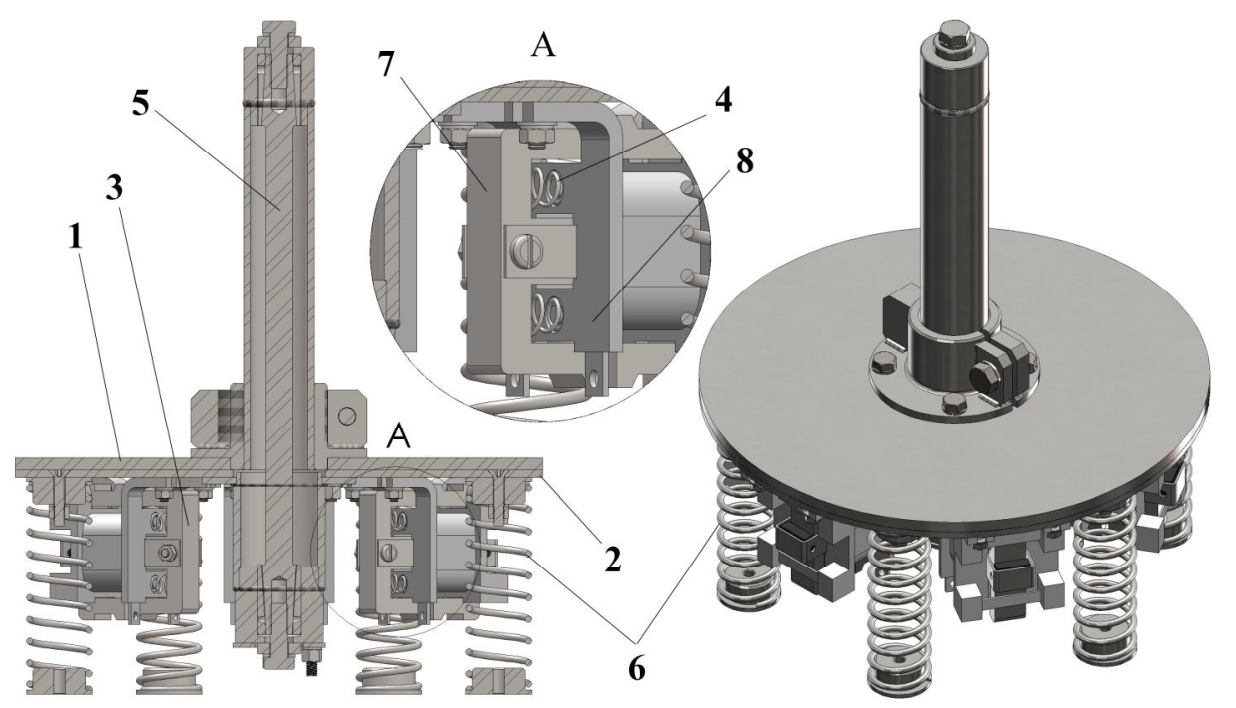

Fig. 1. Design diagram of vibratory finishing machine for lapping flat surfaces of cylindrical parts

Рис. 1. Конструктивна схема вібровикінчувального верстата для притирання плоских поверхонь ичиліндричних і призматичних деталей

Nowadays, the major problem of calculating and designing of such vibratory equipment consists in complicity of adequate describing the dynamics of the spatial (three-dimensional) mechanical oscillatory system of the machine taking into account the periodical plane-parallel motion (circular oscillations) of the laps and of the carrier (flyer) with parts during the excitation by three couples of electromagnets. In this paper, there will be carried out the modelling of the vibratory finishing machine's operation during the process of the laps dressing, i.e. without the carrier with parts. Also, there will be substantiated design and force parameters of the machine's mechanical oscillatory system. The possibilities of ensuring the planeparallel motion of the carrier with parts placed between the working surfaces of the laps will be the subject of further investigation in this field.

Analysis of modern information sources. In publications [2]-[6], [13], the basic stages of designing process and the fundamental techniques of calculating the resonant vibratory machines with electromagnetic drive and in-phase motion of the working bodies are considered. The major of such machines operate on the basis of "zero-stiffness" phenomena. In the works [7] and [8], the basic principles of vibratory treatment of parts are presented and the models of predicting the roughness of the laps' working surfaces of vibratory finishing machines are proposed. On the basis of the results of experimental investigations, the optimality criteria of the process of vibratory finishing treatment of parts are substantiated. In publication [9], the new design of the resonant vibratory finishing machine with electromagnetic drive and circular oscillations of the laps is proposed and the differential equations of the working bodies' motion are derived. In the work [10], the kinematic diagrams of different drives of flatdressing machines are analyzed and the peculiarities of using the cycloidal trajectories of the dresser (dressing tool) for regulating the roughness of the laps' working surfaces are substantiated. In the investigations presented in [11], the kinematic model of the machine for finishing treatment of parts is presented and the simulation modelling of the laps' motion during the parts' lapping is carried out. The adequacy of the proposed models was substantiated on the basis of experimental investigations performed with a help of the high-speed camera. In the patent [12], there is proposed the device for simultaneous lapping the surfaces of cylindrical parts on both sides using the common vibratory finishing machines.

By analyzing the information sources on the subject of the vibratory finishing treatment of the parts' flat surfaces, we can conclude that the problems of dynamic analysis, substantiation of parmeters and 
operation modes, as well as simulation modelling the operation of vibratory lapping machines are not completely solved. In the papers [14] and [15], the investigations of the authors on the mentioned subject were initiated, in particular, three- and four-mass planar diagrams of vibratory finishing machines were considered, the differentials equations of the working bodies' motion were derived, inertial and stiffness parameters of corresponding mechanical oscillatory systems were substantiated, and simulation modelling of the straight-line (translational) oscillatory motion of laps during their dressing was carried out. In this paper the investigations initiated in [14] and [15] will be completed in the direction of developing a spatial (there-dimensional) design (calculation) diagram of mechanical oscillatory system of the improved vibratory finishing machine, of deriving the corresponding differential equations of the oscillating masses' motion, of substantiating the inertial and stiffness parameters and the parameters of excitation of the system, of dynamic analyzing periodical plane-parallel motion (circular oscillations) of the laps during their dressing, of simulation modelling the laps' motion etc.

The purpose of the paper. Substantiation of design (structure), inertial, stiffness and excitation parameters, as well as operation modes of the improved vibratory finishing machine in order to ensure the necessary oscillations' amplitudes of the working masses and the given resonance mode setting-up. Analysis of dynamical processes which occur during "lap over lap" dressing.

Constructing the design (calculation) diagram of mechanical oscillatory system of vibratory finishing machine and stating the idea of its operation. In order to perform further modelling the laps' dressing of vibratory finishing machine using the "lap over lap" method, let us consider the simplified design (calculation) diagram of its mechanical oscillatory system (Fig. 2). The body of the mass $m_{1}$ is the upper lap, which can slide over the working surface of the lower lap (the body of the mass $m_{2}$ ) and is kinematically connected to the lower lap with a help of the elastic system characterized by the stiffness $c_{1}$ and the damping coefficient $\mu_{1}$. The lower lap is mounted (installed) on the unmovable supporting surface (foundation, frame, body etc.) using the vibration isolators with the characteristics of stiffness and damping $c_{i 3}$ and $\mu_{i 3}$, respectively. The excitation of the system's oscillations is performed due to application (exerting) of the periodically changing force $F(t)$ between the reactive masses $m_{3}$ and the lower lap. Herewith, the reactive masses are the armatures of the electromagnets, which are connected to the electromagnets' frames with a help of the elastic elements with stiffness $c_{2}$ and damping coefficient $\mu_{2}$. The electromagnets' frames are attached to the lower lap. Three couples of electromagnets are uniformly placed on the circle of the lower lap, and each couple operates at the same phase. Thus, due to application of the periodically changing forces $F(t)$ between three couples of reactive masses $m_{3}$ with the phase shift of $60^{\circ}$ allows the excitation of periodical plane-parallel motion (circular oscillations) of the laps with respect to each other. In the conditions when the phases of the laps' oscillations are not equal, the process of their mutual (reciprocal) dressing (or, so called, process of "lap over lap" dressing) will be performed. This process will be the most intensive in the conditions of antiphase motion of the laps.

Therefore, the major problem (task) of this paper consists in substantiation of the possibilities of exciting the circular trajectories of the laps' oscillations with the certain phase shift using three couples of electromagnetic vibration exciters attached to the lower lap.

In order to describe the motion of the oscillating masses, let us take the inertial coordinate system with the centre at point $O$ (Fig. 2). Herewith, the axes $O x$ and $O y$ form the horizontal plane, in parallel to which the oscillations of the system's bodies are performed. The axis $O z$ is directed upwards, and the axis $O y$ - in the direction of action of the initial excitation force of one of the couples of electromagnets (i.e. along the diametrical line connecting the centres of the cores of the synchronized electromagnets). The motion of the oscillating masses $m_{1}$ and $m_{2}$ will be described by the corresponding generalized coordinates $x_{1}, y_{1}$ and $x_{2}, y_{2}$, which represent the displacements of the mass centres of the upper and lower laps with respect to their equilibrium position. 
Fig. 2. Design diagram of mechanical oscillating system of vibratory finishing machine

Рис. 2. Розрахункова схема механічної коливної системи вібровикінчувального верстата

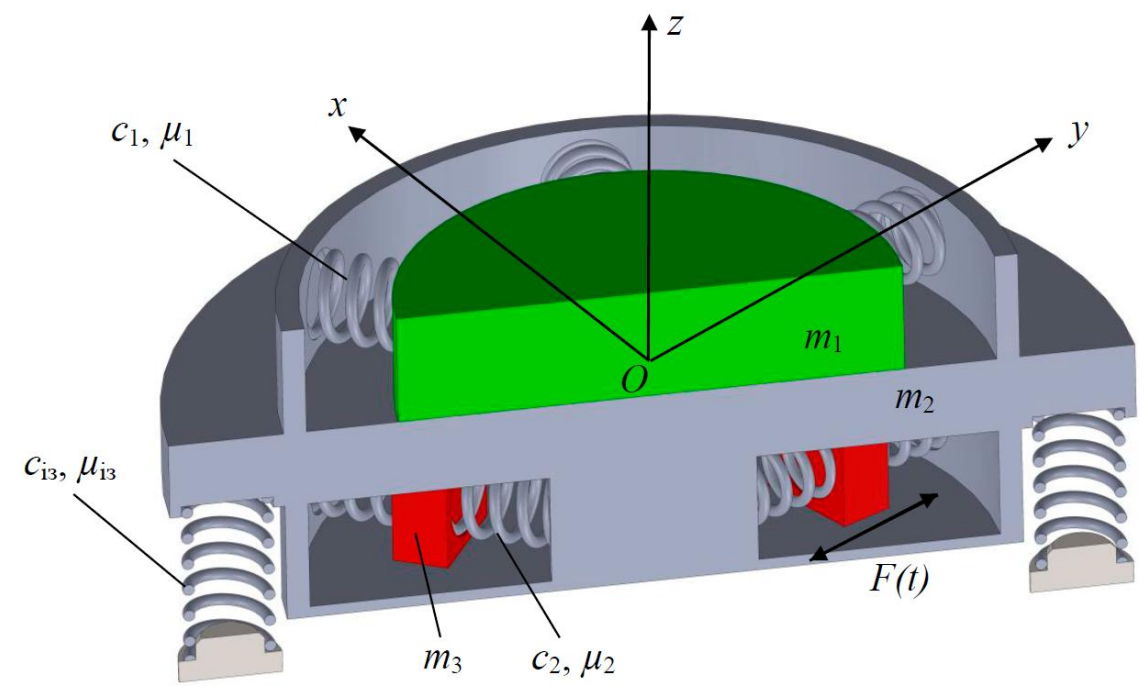

In the plane of contact of the laps' working surfaces, there occurs the friction force, which will be modelled in accordance with the Amontons'-Coulomb's laws. Also, let us assume that the deformations of the elastic elements are performed according to the Hooke's law, and the energy dissipation is proportional to the square of the speed of their deformation.

Developing the mathematical model of the machine's mechanical oscillatory system. The oscillations of the upper lap of the mass $m_{1}$ are kinematically excited through the elastic elements (with the coefficients of stiffness $c_{1}$ and damping $\mu_{1}$ ), which connect it to the lower lap of the mass $m_{2}$ (Fig. 2). In the plane of contact of the working surfaces of the laps, there occurs the friction force proportional to the force of their pressing and directed oppositely to the direction of the speed of motion of the upper laps with respect to the lower lap. Thus, in order to describe the motion of the body $m_{1}$ (upper lap) in accordance with the Newton's second law, let us write the following differential equations:

$$
\begin{aligned}
& m_{1} \cdot(t)+\mu_{1} \cdot\left(\propto(t)-q_{2}(t)\right)+c_{1} \cdot\left(x_{1}(t)-x_{2}(t)\right)=-F_{t x} ;
\end{aligned}
$$

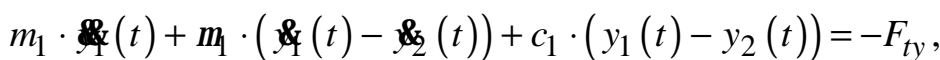

where $\left.F_{t x}=f \cdot m_{1} \cdot g \cdot \operatorname{sign}(\alpha(t)-\underset{\alpha}{\alpha}(t)), F_{t y}=f \cdot m_{1} \cdot g \cdot \operatorname{sign}(t)\right)$ are the projections of the friction force between the laps' contacting surfaces on the axes $O x$ and $O y ; f$ is the coefficient of sliding friction depending on the materials and on the state of the laps' working surfaces; $g$ is free-fall acceleration; $\operatorname{sign}(t)-(t))$ is the function defining (specifying) the direction of the mutual (reciprocal) motion of the upper and lower laps. It can be determined by the following formula:

$$
\begin{aligned}
& \operatorname{sign}(\alpha(t)-(t))=\left\{\begin{array}{l}
1, \text { if }(t(t)-(t))>0 ; \\
-1, \text { if }(t)-(t)-0 ; \\
0, \text { if }(t)-(t)-(t)=0 .
\end{array}\right. \\
& \operatorname{sign}(\psi(t)-(t))=\left\{\begin{array}{l}
1, \text { if }(t(t)-(t))>0 ; \\
-1, \text { if }(t)-(t)<0 ; \\
0, \text { if }(t))=0 .
\end{array}\right.
\end{aligned}
$$

The reactive masses $m_{3}$ (electromagnets' armatures) are excited to perform oscillatory motion by application (exerting) of the periodical excitation force $F(t)$, which occurs between the armatures and 
cores of the electromagnets. Taking into account the fact that the electromagnets are placed in couples, and are diametrically and symmetrically attached to the circle of the lower lap, and each of three couples of electromagnets operates at the same phase, let us derive the differential equations of motion of reactive masses:

$$
\begin{aligned}
& \left.m_{3_{1}} \cdot(t)+\mu_{2} \cdot(t)\right)+c_{2} \cdot\left(x_{3_{1}}(t)-x_{2}(t)\right)=0 \text {; } \\
& m_{3_{1}} \cdot(t)+\mu_{2} \cdot\left(\oint_{1}(t)-c_{2}(t)\right)+c_{2} \cdot\left(y_{3_{1}}(t)-y_{2}(t)\right)=-F \cdot \sin \omega \cdot t \text {; } \\
& m_{3_{2}}(t)+\mu_{2} \cdot\left(\oiint_{2}(t)-(t)\right)+c_{2} \cdot\left(x_{3_{2}}(t)-x_{2}(t)\right)=-F \cdot \sin \left(\omega \cdot t+60^{\circ}\right) \cdot \sin \left(60^{\circ}\right) \text {; } \\
& m_{3_{2}} \cdot(t)+\mu_{2} \cdot\left(\oiint_{2}(t)-c_{2}(t)\right)+\left(y_{3_{2}}(t)-y_{2}(t)\right)=-F \cdot \sin \left(\omega \cdot t+60^{\circ}\right) \cdot \cos 60^{\circ} \text {; } \\
& m_{3_{3}} \cdot(t)+\mu_{2} \cdot\left(\alpha_{3}(t)-(t)\right)+c_{2} \cdot\left(x_{3_{3}}(t)-x_{2}(t)\right)=-F \cdot \sin \left(\omega \cdot t+120^{\circ}\right) \cdot \sin \left(60^{\circ}\right) \text {; } \\
& m_{3_{3}} \cdot(t)+\mu_{2} \cdot\left(y_{3}(t)-c_{2} \cdot\left(y_{3_{3}}(t)-y_{2}(t)\right)=F \cdot \sin \left(\omega \cdot t+120^{\circ}\right) \cdot \cos 60^{\circ},\right.
\end{aligned}
$$

where $m_{3_{1}}, m_{3_{2}}, m_{3_{3}}$ are the total masses of the first, second and third couple of electromagnets; $x_{3_{1}}$, $x_{3_{2}}, x_{3_{3}}, y_{3_{1}}, y_{3_{2}}, y_{3_{3}}$ are the generalized coordinates describing the displacement of the mass centre of each couple of electromagnets projected on the axes $O x$ and $O y$ with respect to their equilibrium positions; $\omega$ is the circular frequency of the excitation force $F(t)$.

The lower lap is performing oscillatory motion due to its kinematical connection to the elastic elements (with the coefficients of stiffness $c_{2}$ and damping $\mu_{2}$ ), which connect the lap to the reactive masses $m_{3_{1}}, m_{3_{2}}, m_{3_{3}}$. In order to describe the motion of the lower lap in accordance with the Newton's second law, let us write the following differential equations:

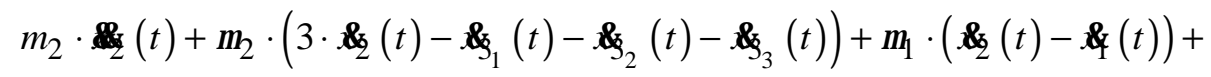

$$
\begin{aligned}
& +c_{2} \cdot\left(3 \cdot x_{2}(t)-x_{3_{1}}(t)-x_{3_{2}}(t)-x_{3_{3}}(t)\right)+c_{1} \cdot\left(x_{2}(t)-x_{1}(t)\right)= \\
& =F \cdot \sin \left(\omega \cdot t+60^{\circ}\right) \cdot \sin \left(60^{\circ}\right)+F \cdot \sin \left(\omega \cdot t+120^{\circ}\right) \cdot \sin \left(60^{\circ}\right)+F_{t x} ; \\
& \left.m_{2} \cdot(t)+\mu_{2} \cdot\left(3 \cdot \oiint_{2}(t)-\oiint_{1}(t)-\oint_{2}(t)-\oiint_{3}(t)\right)+\mu_{1} \cdot(t)-\oiint_{2}(t)\right)+ \\
& +c_{2} \cdot\left(3 \cdot y_{2}(t)-y_{3_{1}}(t)-y_{3_{2}}(t)-y_{3_{3}}(t)\right)+c_{1} \cdot\left(y_{2}(t)-y_{1}(t)\right)= \\
& =F \cdot \sin \omega \cdot t+F \cdot \sin \left(\omega \cdot t+60^{\circ}\right) \cdot \cos 60^{\circ}-F \cdot \sin \left(\omega \cdot t+120^{\circ}\right) \cdot \cos 60^{\circ}+F_{t y} .
\end{aligned}
$$

Taking into account the equations (1)-(3) describing the motion of the oscillating masses of the mechanical system of vibratory finishing machine, we can develop the general mathematical model of the system's motion dynamics during "lap over lap" dressing:

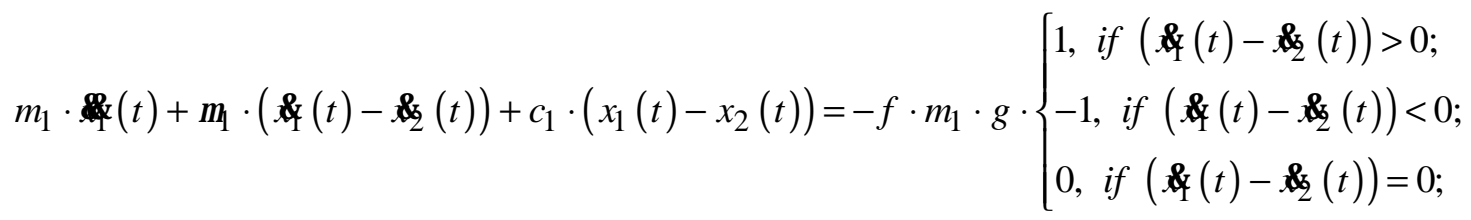

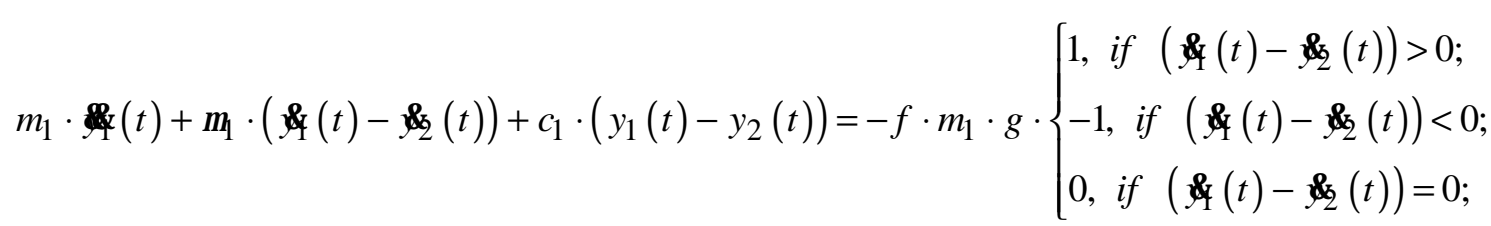




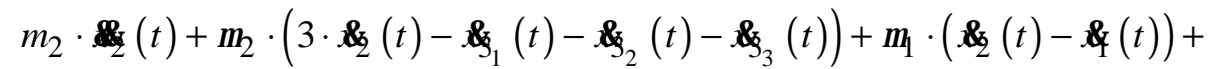

$$
\begin{aligned}
& +c_{2} \cdot\left(3 \cdot x_{2}(t)-x_{3_{1}}(t)-x_{3_{2}}(t)-x_{3_{3}}(t)\right)+c_{1} \cdot\left(x_{2}(t)-x_{1}(t)\right)=F \cdot \sin \left(\omega \cdot t+60^{\circ}\right) \cdot \sin \left(60^{\circ}\right)+ \\
& +F \cdot \sin \left(\omega \cdot t+120^{\circ}\right) \cdot \sin \left(60^{\circ}\right)+f \cdot m_{1} \cdot g \cdot\left\{\begin{array}{l}
1, \text { if }(t)-\text { if }(t))>0 ; \\
-1,(t)-(t))<0 ; \\
0, \text { if }(t))=0 ;
\end{array}\right. \\
& \left.m_{2} \cdot(t)+\mu_{2} \cdot(3 \cdot \underbrace{}_{1}(t)-\oiint_{1}(t)-\oiint_{3}(t))+\mu_{1} \cdot(t)-\oiint_{1}(t)\right)+ \\
& +c_{2} \cdot\left(3 \cdot y_{2}(t)-y_{3_{1}}(t)-y_{3_{2}}(t)-y_{3_{3}}(t)\right)+c_{1} \cdot\left(y_{2}(t)-y_{1}(t)\right)=F \cdot \sin \left(\omega \cdot t+60^{\circ}\right) \cdot \cos 60^{\circ}- \\
& -F \cdot \sin \left(\omega \cdot t+120^{\circ}\right) \cdot \cos 60^{\circ}+F \cdot \sin \omega \cdot t+f \cdot m_{1} \cdot g \cdot\left\{\begin{array}{l}
1, \text { if }(t(t)-\text { if }(t))>0 ; \\
-1,(t)-(t))<0 ; \\
0, \text { if }(t)-(t))=0 ;
\end{array}\right. \\
& m_{3_{1}} \cdot(t)+\mu_{2} \cdot(t)-c_{1}(t)-\left(x_{3_{1}}(t)-x_{2}(t)\right)=0 \\
& \left.m_{3_{1}} \cdot(t)+\mu_{2} \cdot(t)-(t)\right)+c_{2} \cdot\left(y_{3_{1}}(t)-y_{2}(t)\right)=-F \cdot \sin \omega \cdot t \text {; } \\
& m_{3_{2}}(t)+\mu_{2} \cdot\left(\mathscr{G}_{2}(t)-c_{2}(t)\right)+c_{2} \cdot\left(x_{3_{2}}(t)-x_{2}(t)\right)=-F \cdot \sin \left(\omega \cdot t+60^{\circ}\right) \cdot \sin \left(60^{\circ}\right) ; \\
& m_{3_{2}}(t)+\mu_{2} \cdot\left(y_{2}(t)-(t)\right)+c_{2} \cdot\left(y_{3_{2}}(t)-y_{2}(t)\right)=-F \cdot \sin \left(\omega \cdot t+60^{\circ}\right) \cdot \cos 60^{\circ} \text {; } \\
& m_{3_{3}} \cdot(t)+\mu_{2} \cdot\left(\alpha_{3}(t)-(t)\right)+c_{2} \cdot\left(x_{3_{3}}(t)-x_{2}(t)\right)=-F \cdot \sin \left(\omega \cdot t+120^{\circ}\right) \cdot \sin \left(60^{\circ}\right) \text {; } \\
& m_{3_{3}} \cdot(t)+\mu_{2} \cdot\left(\oiint_{3}(t)-c_{2} \cdot\left(y_{3_{3}}(t)-y_{2}(t)\right)=F \cdot \sin \left(\omega \cdot t+120^{\circ}\right) \cdot \cos 60^{\circ}\right. \text {. }
\end{aligned}
$$

In order to check the adequacy of the developed mathematical model (4) and to substantiate the proposed idea of operation of the vibratory finishing machine during the process of the lap' dressing, it is necessary to carry out the simulation modelling of the laps' motion in applied software. Let us use the inertial and stiffness parameters and the parameters of excitation of the machine's mechanical oscillatory system as the input data substantiated in the paper [15].

Simulation modelling of the laps' motion during their dressing. The simulation (numerical) modelling of the laps' motion will be carried out by solving the system of differential equations (4) in MathCAD applied software, which is one of the most widespread and of the most efficient instruments of computer modelling and automation of engineering analysis. In the considered case, it is necessary to model the oscillations of the laps and of the reactive masses (armatures of electromagnetic exciters), which are described by the system of ten linear nonhomogeneous differential equations of the second order with constant coefficients. In order to numerically solve this system of equations let us use the RADAUS method. The technique of determination of the input and initial data, and the design parameters of the mechanical oscillatory system of vibratory finishing machine is substantiated in the paper [15]. In the considered case, for carrying out the modelling of the system's motion let us adopt the following parameters:

- inertial parameters of the investigated system: $m_{1}=m_{2}=9 \mathrm{~kg}, m_{3_{1}}=m_{3_{2}}=m_{3_{3}}=0,4 \mathrm{~kg}$ (these parameters are taken on the basis of machine's design, see Fig. 1);

- stiffness parameters: $c_{1}=4 \cdot 10^{6} \mathrm{~N} / \mathrm{m}, c_{1}=10^{5} \mathrm{~N} / \mathrm{m}, c_{i 3}=10^{3} \mathrm{~N} / \mathrm{m}$;

- excitation parameters: $F=10 \mathrm{~N}, \omega=314 \mathrm{rad} / \mathrm{s}(50 \mathrm{~Hz})$; 
- initial conditions of modelling: initial positions of the working masses $x_{1}(0)=x_{2}(0)=x_{3_{1}}(0)=x_{3_{2}}(0)=x_{3_{2}}(0)=0 ; \quad$ initial velocities of the working masses $\alpha(0)=\left\{(0)=\alpha_{1}(0)=\alpha_{2}(0)=\alpha_{2}(0)=0\right.$;

- coefficient of friction between the working surfaces of the laps: $f=0,09$.

In order to simplify and to reduce the duration of the modelling process let us consider the case of the system motion without taking into account the dissipation of energy in elastic elements. Therefore, in the differential equations (4) let us assume $\mu_{1}=\mu_{2}=0$.

The results of simulation (numerical) modelling of the oscillating masses' motion of the mechanical system of vibratory finishing machine are presented in Figs. 3-4. In particular, in Fig. 3, a, b, there are presented the time dependencies of displacements of the oscillating masses from their equilibrium positions during the machine starting. In the Fig. 3, c, there are the graphical dependencies of the steadystate oscillatory motion of the system's bodies under the influence of periodical excitation forces provided by three couples of electromagnets.
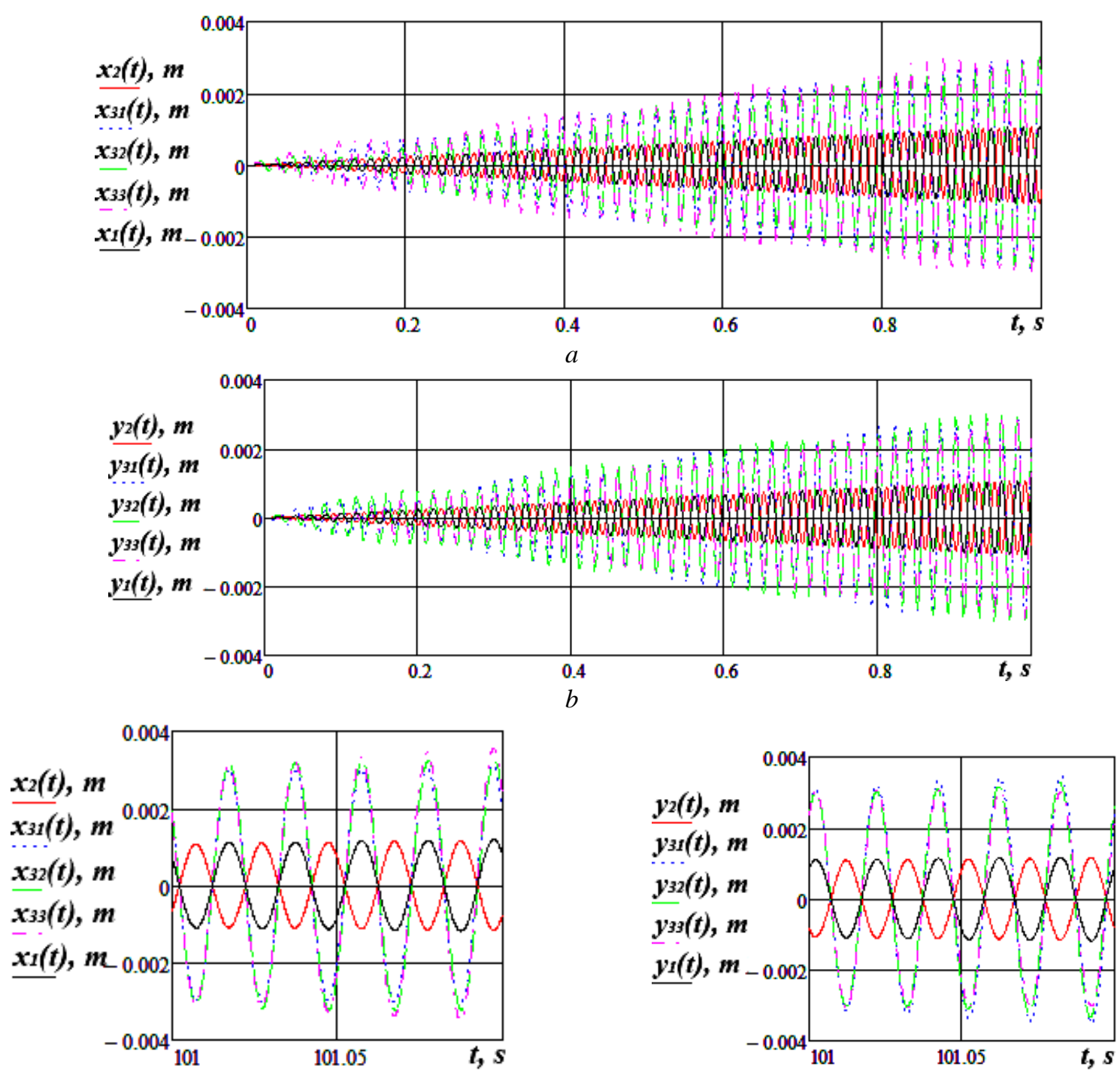

c

Fig. 3. Time dependencies of the oscillating masses displacements during the process of the machine starting $(a, b)$ and in the steady-state operation mode (c)

Рис. 3. Часові залежності відхилень коливних мас в проиесі запуску верстата $(a, b)$ та в усталеному режимі роботи (c) 
As it can be seen in Fig. 3, the upper and the lower laps oscillate at the opposite phases with equal amplitudes $X_{1} \approx X_{2} \approx Y_{1} \approx Y_{2} \approx 1,2 \mathrm{~mm}$. Reactive (exciting) masses move at the opposite phases with respect to the lower lap with amplitudes $X_{3} \approx Y_{3} \approx 3 \mathrm{~mm}$, which are smaller than the width of the air gap between the cores and the armatures of the driving electromagnets. The approximate phase shift between the laps' oscillations along two perpendicular axes $O x$ and $O y$ (see Fig. 2) is equal to $\pi / 2$. This fact allows to make the pre-conclusion about occurring of the circular oscillations of the laps. That is why, in order to substantiate the presence of the antiphase circular oscillations of the laps and to confirm (justify) the proposed idea of "lap over lap" dressing, let us model (draw) in Fig. 4 the trajectories of the planeparallel motion of the laps (i.e. graphical dependencies $y_{1}\left(x_{1}\right)$ and $y_{2}\left(x_{2}\right)$ ).

In Fig. 4, a, there are presented the trajectories of the laps' motion during the first $0.3 \mathrm{~s}$ after the machine start, and in Fig. 4, b, - for the first $1 \mathrm{~s}$. As it can be seen from the obtained results, the laps move along the circular trajectories in opposite senses (directions). The process of the machine starting is uniform, and it takes about $1.5 \mathrm{~s}$ for the machine to reach the stable (steady-state) operation mode, i.e. for the laps to reach the maximal amplitudes of oscillations $X_{1} \approx X_{2} \approx Y_{1} \approx Y_{2} \approx 1,2 \mathrm{~mm}$. Therefore, we can conclude that the prescribed inertial and stiffness parameters of the mechanical oscillatory system of vibratory finishing machine allow ensuring (providing) the efficient process of the laps' dressing by the "lap over lap" method.
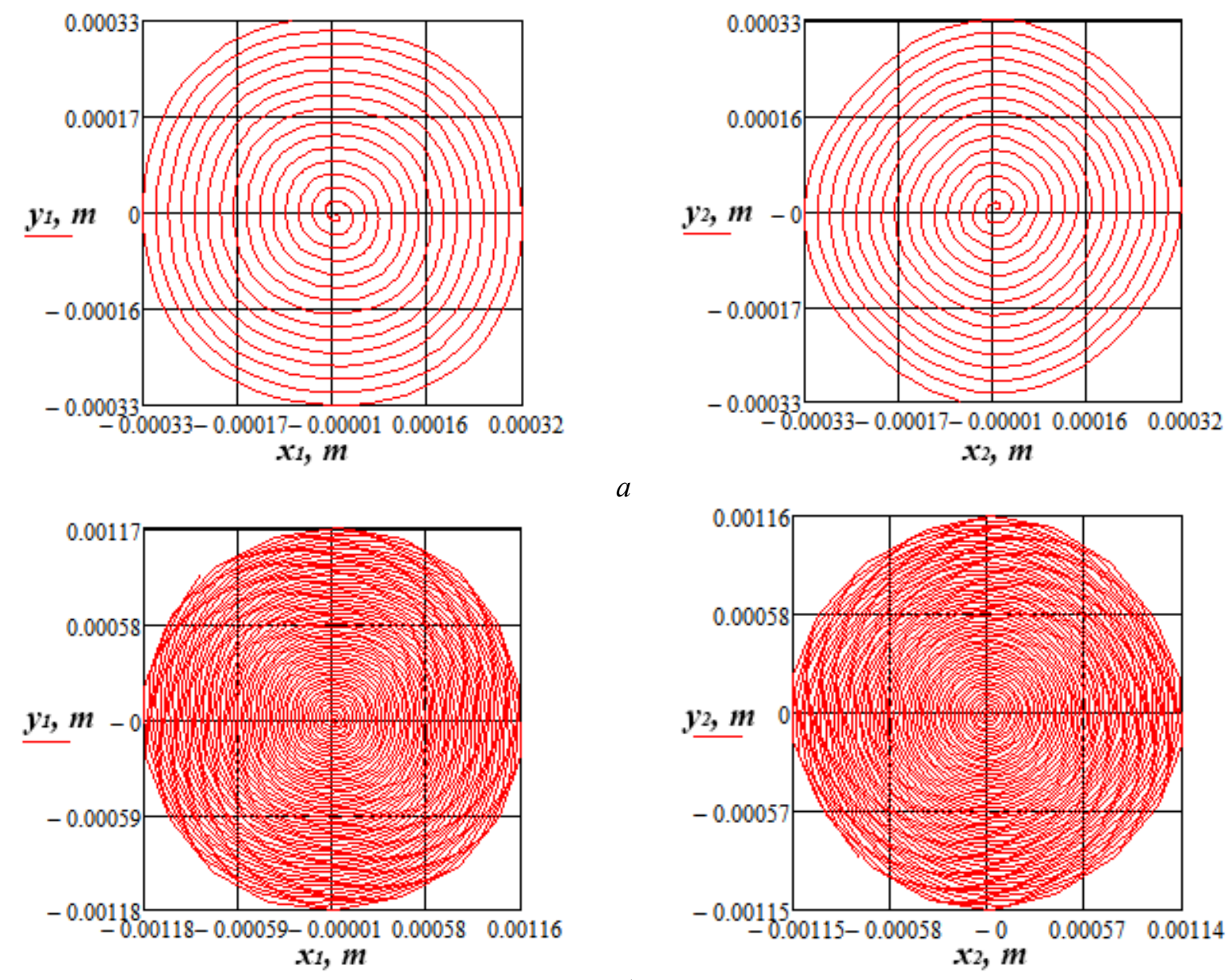

$a$

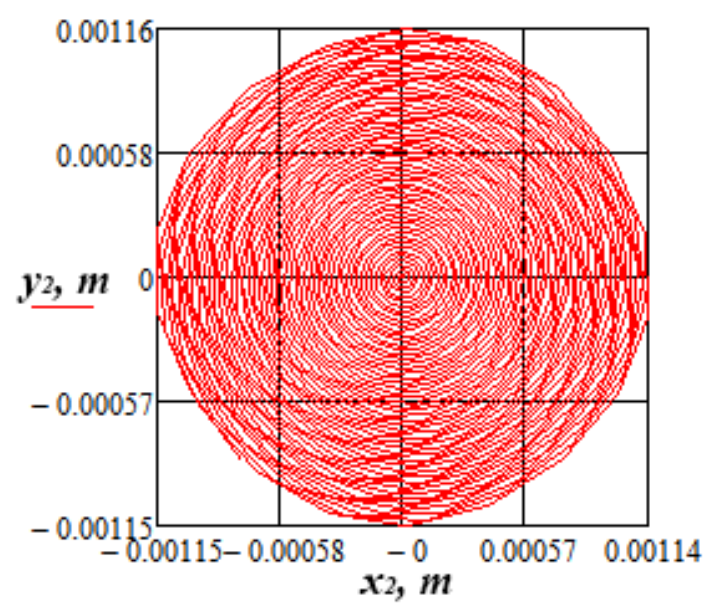

$\sigma$

Fig. 4. Trajectories of the laps' motion during the process of the machine starting: $a$-for the first $0.3 \mathrm{~s}$ after the start; $b$-for the first $1 \mathrm{~s}$ after the start

Рис. 4. Траєкторії руху притирів в процесі запуску верстата: a -за перші 0,3 с після запуску; б - за периу 1 с після запуску 
Conclusions. In the paper, there is proposed the new design solution of the vibratory finishing machine for lapping flat surfaces of cylindrical and prismatic parts. The major advantage of the considered design consists in the use of the rod-type elastic element, which simplifies the possibility of providing the laps' motion along the circular trajectories and of carrying out the process of "lap over lap" dressing. By performing the analysis of modern information sources and investigations on the subject of the article, it was defined that the problems of modelling and studying of the plane-parallel motion of the laps of vibratory finishing machines are purely presented and need to be paid much more attention. It was also concluded, that the problems of substantiation inertial and stiffness parameters, as well as the excitation parameters of the system, dynamic analysis of plane-parallel motion (circular oscillation) of the laps during their dressing, simulation modelling of the laps' motion etc. are not enough studied. That is why, in this paper, there was set a task of analysis of dynamic processes occurring during the "lap over lap" dressing.

The spatial (three-dimensional) design (calculation) diagram of the mechanical system of the improved vibratory finishing machine was proposed. The possibilities of carrying out the laps' dressing by the "lap over lap" method due to the excitation of antiphase circular oscillations of the laps were analyzed. The idea of using three couples of electromagnets placed symmetrically on the circle of the lower lap as the vibration exciters was proposed.

The mathematical model of dynamics of the machine's mechanical oscillatory system consisting of ten linear nonhomogeneous differential equations of the second order with constant coefficients, which describe the motion of each of five oscillating masses: upper and lower laps and three reactive (exciting) bodies, is developed.

In order to check the adequacy of the developed mathematical model and the substantiation of the idea of operation of the vibratory finishing machine during the process of the laps dressing, there was carried out the simulation modelling of the laps' motion in the MathCAD applied software. In order to numerically solve the derived system of differential equations, the RADAUS method was used. The technique of determination of the input data and design (calculation) parameters of the mechanical oscillatory system of vibratory finishing machine was substantiated in the previous publications of the authors. That is why in this paper, the basic parameters of the system were considered as given ones.

Based on the modelling results, the were constructed the time dependencies of the oscillating masses' displacements from their equilibrium positions during the process of the machine starting; the graphical dependencies of the steady-state (stable) oscillatory motion of the system's bodies under the influence of the periodical excitation forces provided by three couples of electromagnets; the trajectories of the laps' motion for the first $0.3 \mathrm{~s}$ and $1 \mathrm{~s}$ after the machine starting. Based on the obtained graphical dependencies (plots), there were made the following conclusions: 1) the upper and the lower laps oscillate at the opposite phases with equal amplitudes $X_{1} \approx X_{2} \approx Y_{1} \approx Y_{2} \approx 1,2 \mathrm{~mm} ; 2$ ) the reactive (exciting) masses move at the opposite phase with respect to the lower lap with the amplitudes $X_{3} \approx Y_{3} \approx 3 \mathrm{~mm}$, which are smaller than the width of the air gap between the cores and armatures of electromagnets; 3 ) the laps move along circular trajectories in opposite senses (directions); 4) after approximately $1.5 \mathrm{~s}$, the machine reaches the stable (steady-state) operation mode, i.e. the maximal amplitudes of the laps' oscillations are reached; 5) the prescribed inertial, stiffness and force parameters of the mechanical oscillatory system of vibratory finishing machine allow providing the effective process of the laps dressing by the "lap over lap" method.

1. P. S. Bernik, and L. V. Jaroshenko, Vibracionnye tehnologicheskie mashiny s prostranstvennymi kolebanijami rabochih organov [Vibratory technological machines with spatial oscillations of working bodies]. Vinnytsia, Ukraine: VGSHN Publ., 1998, 116 p. [in Russian].

2. O. S. Lanets, Vysokoefektyvni mizhrezonansni vibratsiini mashyny z elektromahnitnym pryvodom. Teoretychni osnovy ta praktyka stvorennia [High-performance inter-resonant vibratory machines with electromagnetic drive. Theoretical fundamentals and practice of development]. Lviv, Ukraine: Lviv Polytechnic Publishing House, 2008, 324 p. [in Ukrainian].

3. O. S. Lanets, "Teoriia synfaznykh kolyvan u vibratsiinykh mashynakh z elektromahnitnym pryvodom" ["The theory of in-phase oscillations in vibratory machines with electromagnetic drive"], Vibratsii v tekhnitsi ta tekhnolohiiakh [Vibrations in engineering and technologies], no. 2 (40), pp. 46-59, 2005. [in Ukrainian]. 
4. O. V. Havrylchenko, O. S. Lanets, and Ia. V. Shpak, "Teoriia vibratsiinykh mashyn z elektromahnitnym pryvodom ta synfaznym rukhom kolyvalnykh mas z vrakhuvanniam zhorstkosti vibroizoliatoriv" ["The theory of vibratory machines with electromagnetic drive and in-phase motion of oscillating masses taking into account the stiffness of vibration isolators"], Mashynoznavstvo [Machines Science], no. 9, pp. 19-26, 2005. [in Ukrainian].

5. O. S. Lanets, Ia. V. Shpak, and Iu. P. Sholovii, "Mizhrezonansni vibratsiini prytyralni mashyny z elektromahnitnym pryvodom, rozrobleni na osnovi efektu "Nulovoi zhorstkosti"” ["Inter-Rezonant Vibratory Lapping Machines with Electromagnetic Drive Designed on the Basis of the Effect of "Zero-Stiffness"'], Avtomatyzatsiia vyrobnychykh protsesiv u mashynobuduvanni ta pryladobuduvanni [Industrial Process Automation in Engineering and Instrumentation], vol. 41, pp. 41-48, 2007. [in Ukrainian].

6. O. S. Lanets, O. V. Havrylchenko, Ia. V. Shpak, and V. M. Zakharov, "Vibratsiina vykinchuvalna mashyna z elektromahnitnym pryvodom" ["Vibratory finishing machine with electromagnetic drive"], UA Patent № 938991, February 27, 2014. [in Ukrainian].

7. F. Hashimoto and D. B. DeBra, "Modelling and Optimization of Vibratory Finishing Process", CIRP Ann., vol. 45, no. 1, pp. 303-306, Jan. 1996.

8. F. Hashimoto and S. P. Johnson, "Modeling of vibratory finishing machines", CIRP Ann., vol. 64, no. 1, pp. 345-348, Jan. 2015.

9. R. I. Silin, V. V. Tret'ko, and A. I. Gordeev, "Dinamicheskaja model' i ee realizacija v rezonansnom vibracionnom stanke dlja dovodki ploskih izdelij" [ "Dynamic model and its implementation in resonant vibration machine for flat articles grinding"], Vektor nauki Tol'jattinskogo gosudarstvennogo universiteta [Vektor Nauki of Togliatti State University], vol. 3-1 (33-1), pp. 123-128, 2015. [in Russian].

10. V. F. Makarov and K. R. Muratov, "Analiz oborudovanija dlja finishnoj abrazivnoj obrabotki ploskih precizionnyh poverhnostej izdelij" [ "Equipment analysis for finishing abrasive processing of flat precision surfaces of products"], Vestnik Permskogo nacional'nogo issledovatel'skogo politehnicheskogo universiteta. Mashinostroenie, materialovedenie [Bulletin PNRPU. Mechanical engineering, materials science], vol. 19, no. 1, pp. 170-187, 2017. [in Russian].

11. Y. B. Tian, Z. W. Zhong, and S.J. Tan, "Kinematic analysis and experimental investigation on vibratory finishing”, Int. J. Adv. Manuf. Technol., vol. 86, no. 9-12, pp. 3113-3121, October 2016.

12. A. Fries, "Apparatus for double-sided, grinding machining of flat workpieces," US Patent 9004981, 2015.

13. I. V. Kuzio, O. V. Lanets, and V. M. Gurskyi, "Obhruntuvannia tekhnolohichnoi efektyvnosti dvochastotnykh rezonansnykh vibratsiinykh mashyn z impulsnym elektromahnitnym zburenniam" [ "Substantiation of technological efficiency of two-frequency resonant vibration machines with pulse electromagnetic disturbance"], Naukovyi Visnyk Natsionalnoho Hirnychoho Universytetu [Scientific Bulletin of National Mining University], vol. 3, p. 71-77, 2013. [in Ukrainian].

14. O. V. Havrylchenko, V. M. Korendiy, and V. M. Zakharov, "Formuvannia matematychnykh modelei tryi chotyrymasovykh kolyvnykh system vibrovykinchuvalnykh verstativ" ["Formation mathematical model three and four mass oscillatory systems of vibrating finishing machines"], Visnyk Natsionalnoho universytetu "Lvivska politekhnika" [Bulletin of Lviv Polytechnic National University], no. 866, p. 3-12, 2017. [in Ukrainian].

15. V. Korendiy, and V. Zakharov, "Substantiation of Parameters and Analysis of Operational Characteristics of Oscillating Systems of Vibratory Finishing Machines", Ukrainian Journal of Mechanical Engineering and Materials Science, vol. 3, no. 2, pp. 67-78, 2017.

І. В. Кузьо, В. М. Захаров, В. М. Корендій Національний університет "Львівська політехніка"

\title{
МОДЕЛЮВАННЯ ПРОЦЕСУ ПРАВКИ ПРИТИРІВ ВІБРОВИКІНЧУВАЛЬНОГО ВЕРСТАТА
}

\author{
(C) Кузьо I. В., Захаров В. М., Корендій В. М., 2018
}

Мета роботи. Обгрунтування структури, параметрів і режимів функціонування удосконаленого вібровикінчувального верстата. Аналіз динамічних процесів, які виникають під час правки «притир по притиру». Методи досліджень. Математичну модель руху механічної коливної системи вібровикінчувального верстата будувалия на основі диференціальних рівнянь Лагранжа другого роду. Для опису тертя між робочими поверхнями притирів використано Кулонівську модель тертя. Жорсткісні параметри усіх пружних елементів моделювали відповідно до закону Гука. Втрати енергії в пружних елементах в процесі їх стискання-розтягування враховувалися відповідними коефіцієнтами дисипації (демпфування). Імітаційне моделювання руху механічної коливної системи верстата виконували в програмному продукті MathCAD із розв'язанням виведених диференціальних рівнянь руху системи та 
використанням чисельних методів Рунге-Кутти. Результати роботи. Розглянуто конструктивні i функціональні особливості удосконаленого вібровикінчувального верстата для притирання плоских поверхонь циліндричних і призматичних деталей. Обгрунтовано розрахункову схему його механічної коливної системи та виведено диференціальні рівняння руху коливних мас. Виконано чисельне моделювання руху притирів в процесі їх правки та проаналізовано відповідність отриманих результатів вхідним параметрам моделювання (робота у режимі, близькому до резонансу із заданими амплітудами коливань). Наукова новизна. Вперше: обгрунтовано просторову розрахункову схему механічної коливної системи удосконаленого вібровикінчувального верстата; побудовано математичну модель плоско-паралельного руху коливних мас (з коловими траєкторіями коливань); обгрунтовано можливості здійснення правки робочих органів методом «притир по притиру» за рахунок забезпечення їх колових коливань. Практичне значення. Результати проведених досліджень можна використати під час проектування нових та удосконалення існуючих конструкцій вібровикінчувальних верстатів для фінішного притирання плоских поверхонь циліндричних і призматичних деталей.

Ключові слова: притир, вібровикінчувальний верстат, інерційні параметри, жорсткісні параметри, резонанс, дисипація енергії, коливна система, плоско-паралельний рух, колові коливання.

1. Берник П. С., Ярошенко Л. В. Вибраиионные технологические машины с пространственными колебаниями рабочих органов / Под ред. П. С. Берника. - Винница, 1998. - 116 с.

2. Ланець О. С. Високоефективні міжрезонансні вібраиійні машини з електромагнітним приводом (Теоретичні основи та практика створення): монографія / О. С. Ланець. - Львів: Вид-во Наи. ун-ту «Львівська політехніка», 2008. - 324 с.

3. Ланець О. С. Теорія синфазних коливань у вібраиійних машинах з електромагнітним приводом // Вібраиії в техніиі та технологіях. - 2005. - № 2 (40). - С. 46-59.

4. Гаврильченко О. В., Ланець О. С., Шпак Я. В. Теорія вібрачійних машин з електромагнітним приводом та синфазним рухом коливальних мас з врахуванням жорсткості віброізоляторів // Машинознавство. - 2005. - № 9. - С. 19-26.

5. Ланеиь О. С. Міжрезонансні вібращійні притиральні мамини з електромагнітним приводом, розроблені на основі ефекту “Нульової жсортккості" / О. С. Ланеиь, Я. В. Шиак, Ю. П. Шоловій // Автоматизація виробничих процесів у машинобудуванні та приладобудуванні. - 2007. - Bun. 41. - C. 41-48.

6. Пат. 938991 Україна. Вібраиійна викінчувальна машина з електромагнітним приводом / Ланець О. С., Гаврильченко О. В., Шпак Я. В., Захаров В. М.; заявник і патентовласник Національний університет «Львівська політехніка. - заявл. 27.03.2014; опубл. 27.10.2014, Бюл. № 20.

7. F. Hashimoto and D. B. DeBra, "Modelling and Optimization of Vibratory Finishing Process", CIRP Ann., vol. 45, no. 1, pp. 303-306, Jan. 1996.

8. F. Hashimoto and S. P. Johnson, "Modeling of vibratory finishing machines", CIRP Ann., vol. 64, no. 1, pp. 345-348, Jan. 2015.

9. Силин Р. И., Третько В. В., Гордеев А. И. Динамическая модель и ее реализация в резонансном вибрационном станке для доводки плоских изделий // Вектор науки Тольятттинского государственного университета. - 2015. - Bып. 3-1 (33-1). - C. 123-128.

10. Макаров В. Ф., Муратов К. Р. Анализ оборудования для финишной абразивной обработки плоских прецизионных поверхностей изделий // Вестник Пермского начионального исследовательского политехнического университета. Машиностроение, материаловедение. - 2017. - T. 19, № 1. - С. 170-187.

11. Y. B. Tian, Z. W. Zhong, and S.J. Tan, "Kinematic analysis and experimental investigation on vibratory finishing”, Int. J. Adv. Manuf. Technol., vol. 86, no. 9-12, pp. 3113-3121, October 2016.

12. A. Fries, "Apparatus for double-sided, grinding machining of flat workpieces," US Patent 9004981, 2015.

13. Кузьо I. В. Обгрунтування технологічної ефективності двочастотних резонансних вібраиійних машин з імпульсним електромагнітним збуренням / I. В. Кузьо, О. С. Ланещь, В. М. Гурський // Науковий вісник Національного гірничого університету. - 2013. - № 3. - С. 71-77.

14. Гаврильченко О. В., Корендій В. М., Захаров В. М. Формування математичних моделей три- $i$ чотиримасових коливних систем вібровикінчувальних верстатів // Вісник Національного університету "Львівська політехніка". Серія "Динаміка, міџність та проектування машин і приладів". - 2017. - № 866. - С. 3-12.

15. V. Korendiy, and V. Zakharov, "Substantiation of Parameters and Analysis of Operational Characteristics of Oscillating Systems of Vibratory Finishing Machines", Ukrainian Journal of Mechanical Engineering and Materials Science, vol. 3, no. 2, pp. 67-78, 2017. 